\title{
Montoneros y el dilema de la patrulla perdida: la política y las armas (1974-1980)
}

Montoneros and the dilemma of the lost patrol: politics and weapons (1974-1980)

\section{Rocío Soledad Otero*}

Resumen: El artículo polemiza con la clave interpretativa que afirma que tras el pasaje a la clandestinidad en 1974 se dio un proceso de militarización creciente en la organización Montoneros. Para ello, sistematiza y analiza las orientaciones e iniciativas políticas y militares de Montoneros entre 1974 y 1980, en base a una hipótesis que afirma que, pese a la clandestinización, durante todo ese período se destinaron esfuerzos tanto al accionar militar como al político.

Palabras Clave: Montoneros, clandestinidad, militarización, peronismo, marxismo, obstáculo epistemológico.

\begin{abstract}
The article polemizes with the interpretative key that affirms that after the passage to the underground in 1974 there was a process of increasing militarization in the organization Montoneros. To this end, it systematizes and analyzes the political and military orientations and initiatives of Montoneros between 1974 and 1980, based on a hypothesis that affirms that, despite clandestinization, during this entire period efforts were devoted both to military and political actions.
\end{abstract}

Key words: Montoneros, secrecy, militarization, peronism, marxism, epistemological obstacle.

Recibido: 29 marzo 2019 Aceptado: 4 septiembre 2019

\section{Introducción}

En los géneros académico, periodístico y testimonial existe una clave de lectura que, con distintas variantes, plantea centralmente que, al pasar a la clandestinidad en septiembre de 1974, la organización Montoneros inició un proceso de militarización creciente que la condujo a circunscribir su accionar al enfrentamiento armado y a abandonar las tareas políticas, con el consecuente aislamiento respecto de las masas, cuyas voluntades había

\footnotetext{
* Argentina. Doctora en Ciencias Sociales (FSOC-UBA). Este trabajo forma parte de mi proyecto de investigación postdoctoral financiado por CONICET, con sede en el Instituto Gino Germani (FSOC-UBA). Docente (UBA y UMET), rociootero3000@hotmail.com.
} 
sabido concitar en la etapa previa. Siguiendo esa clave interpretativa, acontecimientos tales como el fracaso de la última operación de Montoneros en el país, la contraofensiva de 1979/1980, con su alto costo en vidas, pueden ser reducidos a un mero punto de llegada inevitable de esa tendencia. Por otro lado, las múltiples variantes políticas ensayadas en esos años, que orbitaron en buena medida alrededor de replanteos y reformulaciones del peronismo, pueden quedar reducidos analítica y conceptualmente a esa lógica militarista. En sus lineamientos generales, esta clave de lectura no es privativa de Montoneros. Ya desde fines de la década del setenta y comienzos de la del ochenta, en una época a caballo entre el cierre del ciclo histórico revolucionario y la recuperación democrática, emergieron críticas al accionar de las organizaciones armadas. Es el caso de las voces que en el exilio mexicano habitaron la revista Controversia. Como afirma Martín Mangiantini, en ese marco interpretativo inicial, el militarismo, como opuesto a la construcción política, se posicionó como el problema central de las organizaciones político-militares. ${ }^{1}$

En los últimos años se han esbozado críticas al enfoque de la militarización. Según Vera Carnovale, existe un conjunto de lecturas, en su mayoría provenientes de ex militantes, que plantea que las organizaciones armadas se vieron atravesadas por una militarización que las llevó a un progresivo aislamiento, de modo que la violencia terminó perdiendo el carácter esencialmente político que había tenido en su origen. Para Carnovale es necesario problematizar la potencia explicativa de ese enfoque, ya que presenta a la violencia armada y a la política como términos diferenciables e incluso opuestos; y poner en crisis una premisa complementaria: que la violencia revolucionaria fue esencialmente defensiva, razón por la cual, la continuidad de la lucha armada tras la recuperación democrática de 1973 habría sido un desajuste o un desvío. Según Carnovale, dado que en los años setenta la violencia armada y la política no fueron términos diferenciables sino complementarios, la militarización sería constitutiva de las experiencias armadas. ${ }^{2}$

Para el caso puntual de Montoneros, Daniela Slipak plantea que la clave interpretativa de la militarización está presente en muchas miradas retrospectivas (tanto académicas como testimoniales) junto a otras ideas como las de burocratización, vanguardismo y una cúpula dirigente equivocada; que opera como un modo de preservar los valores que originalmente impulsaron aquellas luchas de las estrategias equívocas que condujeron a la derrota del proyecto revolucionario; y que proviene de la militancia de la época. Para la autora, en algunos casos, la militarización aparece como un desvío respecto del proyecto político originario, mientras que, en otros, como una característica que existió durante todo el derrotero de los grupos armados, pero sólo en sus direcciones, recurriendo así a la figura del quiebre entre estas y la militancia. Otras miradas, profundiza Slipak, hibridarían ambos argumentos para explicar la transformación de los principios políticos iniciales mediante la figura del espejo, aduciendo que se dio una imitación de otros actores de la coyuntura (tanto las Fuerzas Armadas como otros grupos revolucionarios) y, al mismo tiempo, hacen responsables a las cúpulas. Slipak concluye que resulta necesario comprender

\footnotetext{
1 Mangiantini, Martín, “Los estudios sobre la lucha armada y las organizaciones político-militares en los años setenta. Hacia un balance historiográfico de su producción reciente (2001-2015)", Estudios, No 34, Córdoba, 2015, 79-99.

2 Carnovale, Vera, "Más allá de la militarización: la violencia revolucionaria, esperanza y promesa de emancipación", Pasado abierto, No 2451, 2015, 127.
} 
la imbricación constitutiva entre política y violencia que caracterizó a la experiencia setentista, algo que la persistencia de ciertas claves interpretativas dificultaría, cuarenta años después de haber sido elaboradas en el seno de las experiencias contestatarias. ${ }^{3}$

En este sentido, Germán Gil es taxativo: para el autor el militarismo montonero no nació en 1974 ni fue introducido por actores exógenos a los grupos originarios, sino que existió siempre y estaba inscripto en la estrategia movimientista por la cual esa organización asumió que las diferencias al interior del peronismo debían quedar en un segundo plano para desplegar las potencialidades revolucionarias del movimiento. En palabras de Gil:

¿O acaso una organización cuya finalidad era la de constituirse en "brazo armado" de un movimiento político masivo y mayoritario no lleva en sí una vocación de militarizarse, aunque más no sea como una consecuencia y una expresión de esa 'división del trabajo' político?4

Gil plantea que fue precisamente la conversión de Montoneros del movimientismo al tendencismo, es decir, cuando la organización decidió impulsar una política territorial de masas y enfocar sus esfuerzos en actividades legales, lo que frenó momentáneamente la militarización.

Pese a la recurrencia de la lectura sobre la militarización montonera, la noción no tiene un sentido unívoco. Dos trabajos de investigación contienen los mayores esfuerzos al respecto y, por su carácter consagratorio, sus argumentos orbitan directa o indirectamente en las interpretaciones sobre el fenómeno montonero: los de Richard Gillespie y Pilar Calveiro.

A principios de los ochenta se conoció la investigación de Gillespie, que aún hoy sigue siendo la única reconstrucción histórica global sobre Montoneros y la principal obra de referencia. Allí, el politólogo inglés consagró académicamente la interpretación que afirma que desde las transformaciones organizativas que siguieron al pasaje a la clandestinidad "hubo indicios de que los factores militares podían pesar más que los criterios políticos en la toma de decisiones por los Montoneros". 5 Para el autor, poco después el militarismo se volvió un rasgo dominante: la lucha armada adquirió una dinámica propia en la que se perdió la perspectiva respecto al accionar militar, lo que condujo a Montoneros a una lógica que se terminó pareciendo al terrorismo practicado al azar. Según Gillespie, se dio un espiral reactivo de violencia que llevó a una contradicción constante entre los criterios políticos y los militares: cada vez que fue necesario definir una estrategia, el razonamiento político, que exigía profundizar la penetración territorial, chocó con la lógica militar, que conducía al aislamiento por razones de seguridad. "Puede comprenderse por qué fue el polo militar de esa contradicción el que se impuso de forma creciente" concluye. ${ }^{6}$ No sorprende pues, dado que esta clave estructura su interpretación sobre el fenómeno, que la Contraofensiva de 1979/80 sea reducida a una "exhibición más de militarismo" y tomada

\footnotetext{
3 Slipak, Daniela, "Sobre desvíos, espejos y cúpulas. Las disidencias montoneras y las lecturas sobre los años setenta", Izquierdas, No 32, Santiago de Chile, 2017, 1-13.

4 Gil, Germán, La izquierda peronista, Buenos Aires, Prometeo, 2019, 263.

${ }^{5}$ Gillespie, Richard, Soldados de Perón. Historia crítica sobre los Montoneros, Buenos Aires, Sudamericana, $2008,277$.

6 Ibid., 303.
} 
como la prueba de que las iniciativas políticas de los Montoneros hacia los trabajadores fueron "incorregiblemente militaristas". 7

En Política y/o violencia. Una aproximación a la guerrilla de los años 70, el trabajo tal vez más acabado conceptualmente sobre la cuestión de la militarización, Pilar Calveiro también identifica el pasaje a la clandestinidad de Montoneros como el desencadenante del proceso de militarización. Para la autora, en los primeros años de actividad, los blancos del accionar armado de Montoneros habían tenido un claro fin político. La organización suponía, como todas las vanguardias revolucionarias de la época, que el accionar militar generaba conciencia política. Luego, en la coyuntura de la recuperación democrática de 1973 y mediante una mezcla de foquismo y populismo, Calveiro sostiene que se dio un proceso de apertura como parte de los intentos de Montoneros por insertarse en el peronismo, que poco después se desvirtuó y empobreció a medida que la organización se distanció del movimiento. Según Calveiro, el proceso de la militarización montonera tuvo dos vertientes: el intento de construir un ejército popular similar a un ejército regular, que se inició con la clandestinización, cuando la estructura de la organización se especializó en las actividades militares; y la escalada represiva que obligó a abandonar el trabajo de base. Pero lo central, para Calveiro, es que desde la clandestinización Montoneros se lanzó "a una demostración de fuerza militar, con la ilusión de recuperar a través de ella el espacio político perdido" 8 , lo que a su juicio mostró la supervivencia de las concepciones foquistas originales, pero transmutadas y potenciadas tras el objetivo de formar un ejército con características de uno regular.

Calveiro está convencida de que el proceso de militarización creciente debilitó internamente a las organizaciones, puesto que habría propiciado los lazos de autoridad en detrimento de los vínculos de compañerismo, que habían unido históricamente a la militancia, conduciendo a la guerrilla a reproducir en su seno, las formas y técnicas del poder establecido. ${ }^{9}$ Asimismo, juzga que el sobredimensionamiento de lo militar hasta ocupar el espacio de lo político, produjo "una verdadera confusión entre uno y otro y la reducción de uno al otro". ${ }^{10}$ Finalmente, cabe destacar que para Calveiro la militarización convirtió al opositor en enemigo y a la lucha política en guerra; y determinó tres problemas estructurales vinculados a la política interna: una simplificación de lo político como un problema meramente organizativo (internamente criticado como "aparatismo"); una falta de participación en los mecanismos de promoción y en la toma de decisiones; y un disciplinamiento de los desacuerdos alrededor de criterios eminentemente militares. ${ }^{11}$

Distintas lecturas identifican en las transformaciones estructurales que siguieron al pasaje a la clandestinidad el origen del problema de la militarización montonera. Según Ernesto Salas, al organizar a los militantes en milicias, disponer una retirada estratégica e impulsar una ofensiva táctica militar se produjo el "abandono de las tareas políticas, insertas en mayor o menor medida en las redes populares", lo que "disoció a la organización de las

\footnotetext{
7 Ibid., 393 y 395.

8 Calveiro, Pilar, Política y/o violencia. Una aproximación a la guerrilla de los años 70, Buenos Aires, Verticales de Bolsillo, 2008, 83.

${ }_{9}$ Ibid., 95.

10 Ibid., 112.

11 Ibid., 111 y ss.
} 
demandas sociales y políticas, alentando un creciente y renovado vanguardismo".12 Para Julieta Bartoletti, Montoneros había consolidado una "identidad organizativa" que combinaba la práctica armada con la identificación e inserción efectiva en el movimiento peronista mediante el impulso de frentes de masas. Luego, debido a la crisis del peronismo, impulsó transformaciones organizativas que la habrían conducido a una fuerte militarización. ${ }^{13}$

En cierto modo, la idea de que tras el pasaje a la clandestinidad se inició un proceso que hipertrofió las actividades militares y atrofió las políticas, está presente también en interpretaciones autocríticas retrospectivas provenientes de la experiencia, montonera, tanto de sus militantes como de sus conducciones. El ex dirigente montonero Roberto Perdía ha sostenido que en el marco de la violencia de la que era objeto la militancia en general, Montoneros perdió el rumbo y cometió su desatino más grande al volver a la clandestinidad, creyendo erróneamente que para asegurar su continuidad debía enfrentarse la violencia paraestatal con las armas. Según afirma, eso llevó a la organización a cerrarse sobre sí misma, a dejar al descubierto a los militantes de las agrupaciones de masas y a participar de un proceso de generalización de la violencia que condujo a los extremos. ${ }^{14}$ Elementos de esa autocrítica ya estaban presentes en la primera edición del libro autobiográfico de Perdía, publicado en 1997.15 Juan Gasparini señala que Montoneros "terminó siendo una organización que promocionaba la valentía física, la generosidad y el honor para encarar la lucha armada pero ahogaba el coraje intelectual que enriquece la elaboración de cualquier línea política", enfocando así su crítica en la preeminencia de la lógica militar por sobre la política. ${ }^{16}$

Entre los testimonios que conforman el trabajo Violencia y política en los 70. No dejés que te la cuenten de Ernesto Jauretche, emerge como principal error de Montoneros el haber sobredimensionado su poder de fuego propio frente al Ejército y como una de las explicaciones de dicho proceso, la fusión en 1973 de Montoneros con Fuerzas Armadas Revolucionarias de raigambre marxista e identidad peronista (FAR), de donde provendría el sesgo militarista que cobró en los años sucesivos. ${ }^{17}$ Esa apreciación es compartida por muchos militantes, para quienes la conducción conformada tras la fusión adquirió un sesgo marxista que potenció los rasgos foquistas y vanguardistas. ${ }^{18}$ José Amorín también afirma que tras el pasaje a la clandestinidad se dio una militarización que vincula al proceso de fusión con FAR y su influencia en la toma de decisiones. ${ }^{19}$ En los testimonios que componen La Voluntad. Una historia de la militancia revolucionaria en la Argentina, también aparece la idea de que tras el pasaje a la clandestinidad aumentaron las operaciones militares y en particular los "ajusticiamientos", al tiempo que se reconstruyen las críticas que se hicieron en ese

\footnotetext{
12 Salas, Ernesto, De resistencia y lucha armada, Buenos Aires, Ed. Punto de Encuentro, 2013, 71.

13 Bartoletti, Julieta, Montoneros: de la movilización a la Organización. Un caso paradigmático de militarización, tesis de doctorado, UGS, 2010.

14 Perdía, Roberto, Montoneros. El peronismo combatiente en primera persona, Buenos Aires, Planeta, 2013,405 y ss.

15 Perdía, Roberto, La otra historia. Testimonio de un jefe montonero, Río Negro, Grupo Ágora, 1997, 236 y ss.

16 Gasparini, Juan, Montoneros. Final de cuentas, La Plata, De la Campana, 2008, 135.

17 Jauretche, Ernesto, Violencia y política en los 70. No dejés que te la cuenten, Buenos Aires, Ediciones del Pensamiento Nacional, 1997, 244, 251 y ss.

18 Salcedo, Javier, Los montoneros del barrio, Tres de Febrero, Universidad Nacional de Tres de Febrero, 2011, 191 y ss.

19 Amorín, José, Montoneros: la buena historia, Buenos Aires, Buenos Aires, Catálogos, 2005, 245, 270 y ss.
} 
entonces a la clandestinización: el peligro de abandonar los espacios públicos, potenciar las tendencias guerrilleristas e iniciar una tendencia suicida. ${ }^{20}$ En sus memorias, Gregorio Levenson identifica las características violentas que asumió el enfrentamiento interno del peronismo y en particular, el pasaje a la clandestinidad y el enfrentamiento armado con las fuerzas de seguridad, como uno de los errores más graves cometidos. ${ }^{21}$ Más recientemente, Ricardo Grassi reproduce la idea de que el pasaje a la clandestinidad fue un error ideologicista y militarista y una decisión desesperada. ${ }^{22}$

Recuperando a Gastón Bachelard, este trabajo tiene como estímulo inicial la idea de que la clave de lectura de la militarización opera como un obstáculo epistemológico: "lo que cree saberse claramente ofusca lo que debiera saberse".23 Por ello, tiene por objeto sistematizar y poner de relieve las orientaciones e iniciativas políticas y militares de Montoneros entre 1974 y 1980, a partir de una hipótesis a contramano de las lecturas que, en forma general, consideran que a partir del pasaje a la clandestinidad se dio una militarización creciente que asfixió la política. La hipótesis sostiene que desde el pasaje a la clandestinidad y hasta el ocaso de Montoneros, tanto las prácticas políticas como las militares, mantuvieron una presencia constante. Así, en ese período las decisiones de esa organización mostraron constantemente una doble apuesta, en vista de la cual se realizaron notables esfuerzos materiales y simbólicos. Por un lado, al trabajo político, a través de una variedad de iniciativas sindicales y reivindicativas y mediante múltiples esfuerzos por reordenar la identificación peronista. Por otro, al trabajo militar, mediante la organización de milicias, la constitución de un Ejército y el despliegue de campañas ofensivas.

Así, este trabajo busca mostrar que la dialéctica entre los factores políticos y militares, presente desde los orígenes, no cejó cuando se decidió el retorno a la lucha armada en 1974, y que el despliegue de los factores militares no impidió seguir desarrollando una amplia y variada cantidad de actividades de carácter político. Polemizar con la clave de lectura de la militarización mediante una sistematización de las distintas iniciativas de Montoneros en el período, permitirá poner de relieve la escasa atención que han merecido muchos capítulos de su historia tras el pasaje a la clandestinidad, al tiempo que plantear una agenda de temas de investigación.

Con el fin de poner a prueba esta hipótesis, entablaré un diálogo con parte de la bibliografía sobre Montoneros. Las fuentes utilizadas son variadas. Se analizan notas, comunicaciones y artículos publicados en la revista política Evita Montonera; en el órgano oficial del Ejército Montonero, Estrella Federal; en el folleto del Partido y Ejército montoneros El Montonero; en el boletín de noticias Vencer. También, folletos, circulares internas, boletines, documentos críticos; recortes de prensa comercial del exterior; y libros biográficos y testimoniales.

\footnotetext{
20 Anguita Eduardo y Caparrós, Martín, La Voluntad. Una historia de la militancia revolucionaria en la Argentina, Tomo 4, Buenos Aires, Booket, 1998, 102 y ss.

${ }^{21}$ Levenson, Gregorio, De los bolcheviques a la gesta montonera, Buenos Aires, Colihue, 2000, 187.

22 Grassi, Ricardo, El Descamisado. Periodismo sin aliento, Buenos Aires, Sudamericana, 2015, 352-353.

23 Bachelard, Gastón, La formación del espíritu científico, México, Siglo XXI, 2000, 16.
} 


\section{Los antecedentes}

Los primeros capítulos de la historia de Montoneros son conocidos: la organización salió a la luz públicamente el 29 de junio de 1970 con la operación de secuestro y posterior fusilamiento del Gral. Pedro Eugenio Aramburu, uno de los responsables del golpe de Estado que en 1955 había derrocado al presidente en ejercicio Juan Domingo Perón. Desde su surgimiento Montoneros afirmó que asumía la lucha armada, entendida como una forma de resistencia popular, y que se identificaba con el peronismo y sus vertientes radicalizadas. ${ }^{24}$

En efecto, entre 1970 y 1972, Montoneros desplegó una estrategia de resistencia armada contra la dictadura de la autodenominada "Revolución Argentina", que gobernaba el país desde 1966 y que mantenía la proscripción del peronismo. En dicha etapa, sus principales objetivos políticos fueron el desgaste de la dictadura, el regreso de Perón y un proyecto de poder que consideraban compartido con el líder del peronismo, la instalación del "socialismo nacional". 25

Pese a haber manifestado inicialmente su rechazo a una salida electoral, desde fines de 1972 y por pedido expreso de Perón, la organización asumió un rol activo en la campaña que llevó a la presidencia a Héctor Cámpora el 25 de mayo de 1973. En esa etapa, relegó a un segundo plano la estrategia de resistencia armada y se volcó a la creación de frentes de masas propios mediante la estructura conocida como JP Regionales y distintos agrupamientos de jóvenes, villeros, inquilinos, mujeres y trabajadores. Montoneros se consolidó así como una organización político-militar, abandonó la clandestinidad y pudo impulsar acciones de superficie que ampliaron su margen de acción legal y la transformaron en protagonista de la campaña electoral. ${ }^{26}$ Esto trajo como resultado lo que en la época se llamó -con cierto dejo despectivo- "el engorde": la inclusión de cuadros quizás mal preparados y, en todo caso, sin las experiencias comunes de lucha que caracterizaban a los militantes montoneros.

El 20 de junio Perón regresó definitivamente al país. En Ezeiza, la multitudinaria concentración organizada para recibirlo derivó en una masacre con muertos y heridos, razón por la cual el líder nunca arribó al lugar. Al otro día, dirigió un mensaje al pueblo argentino en el que se refirió a la necesidad de pacificar el país y a la existencia de enemigos internos del movimiento. Esos episodios marcaron el inicio de una etapa en la que la lucha facciosa del peronismo se volvió violenta, y en la que el líder comenzó un distanciamiento de los sectores de la izquierda peronista. ${ }^{27}$

Pocas semanas después y como un corolario de ese distanciamiento, Cámpora renunció a la presidencia y ocupó su lugar Raúl Lastiri, hombre cercano a la derecha peronista y a uno de sus principales cabecillas, José López Rega. En septiembre de ese año, en un nuevo llamado electoral, el viejo líder y su esposa y compañera de fórmula, María

24 Ver Otero, Rocío, “Las memorias de la Resistencia Peronista en los orígenes de Montoneros”, Travesía. Revista de historia económica y social, $\mathrm{N}^{\mathrm{o}} 1$, vol. 21, 1-27.

25 Ver Otero, Rocío, “Montoneros y Perón ¿un diálogo de sordos? Apostillas sobre el socialismo nacional (1967/1972)", Nuevo Mundo Mundos Nuevos, París, diciembre 2018.

26 Ver Salas, Ernesto, “El errático rumbo de la vanguardia montonera”, en ob.cit., 61-76.

27 Ver Nahmías, Gustavo, La batalla peronista. De la unidad imposible a la violencia politica (Argentina 1969-1973), Buenos Aires, Edhasa, 2013, 295 y ss. 
Estela Martínez, conocida como "Isabelita" o Isabel Perón, ganaron la contienda con una amplia mayoría. A principios de octubre se difundió el "Documento Reservado" firmado por el Consejo Superior del Movimiento Nacional Justicialista, en donde se llamaba a combatir a la "infiltración marxista". 28

La renuncia de Cámpora y la elección de Isabel como candidata a la vicepresidencia, fueron interpretadas por Montoneros como un avance de la derecha peronista. No obstante, durante unos meses, continuó dando muestras de apoyo a Perón. Con el correr de las semanas, mientras que Perón insistía públicamente en la necesidad de que la organización se reconvirtiera, abandonara las armas y se comprometiera con la pacificación nacional, la reconstrucción democrática y la construcción de una alianza entre trabajadores y empresarios conocida como "Pacto Social"; Montoneros se reafirmó poco a poco en la instalación del socialismo como objetivo y criticó el modelo económico argumentando que los intereses de la clase trabajadora no habían sido contemplados. Además, criticó las medidas tendientes a desarticular el accionar de las organizaciones revolucionarias (como las reformas al Código Penal) y desde fines de 1973 hizo públicas las diferencias ideológicas con el líder, reconoció que se había construido una imagen idealizada y que éste no buscaba la construcción del socialismo. Comenzó así un proceso de enfrentamiento que derivó en una ruptura abierta el $1^{\circ}$ de mayo de 1974 durante el festejo del día del Trabajador, tras un verano signado por el acrecentamiento de las tensiones mutuas. ${ }^{29}$

El $1^{\circ}$ de julio de 1974 Perón falleció y en su lugar asumió Isabel. Los casi dos años de su gobierno se caracterizaron por el deterioro de la economía, el vacío de poder, la persecución, la censura de prensa, la violencia política y la represión ilegal. ${ }^{30} \mathrm{La}$ desaparición física de Perón signó una nueva etapa en la historia de la relación entre el peronismo y los Montoneros.

\section{La vuelta a la resistencia, las milicias y el peronismo auténtico}

En septiembre de 1974 tuvo lugar una conferencia de prensa en Buenos Aires en la que participaron representantes de todas las agrupaciones que respondían a Montoneros. Allí se comunicó públicamente que se reanudaba la resistencia armada y se encaraba la tarea de organizar las milicias ideadas por Evita "para que todo el pueblo argentino participe activamente en todas las formas de enfrentamiento que se darán en esta etapa". ${ }^{31}$ Entre los fundamentos de la decisión, se adujo que desde el 25 de mayo de 1973 Montoneros había apoyado al gobierno popular, pero que el proceso de liberación se había desnaturalizado y se encontraban "agotados todos los medios, esfuerzos y propuestas para lograr un reencauzamiento" ante el "contenido antiperonista, antipopular, represivo y promonopólico" del gobierno de Isabel. ${ }^{32} \mathrm{Si}$ bien se anunciaba una vuelta a las formas armadas de lucha, en esa conferencia, Montoneros hizo públicas un conjunto de exigencias

\footnotetext{
28 Ver Franco, Marina, Un enemigo para la nación. Orden interno, violencia y "subversión", Buenos Aires, FCE, 2012, 45-58

29 Ver Caviasca, Guillermo, “Los Montoneros y el enfrentamiento con Perón”, Dos caminos. PRT-ERP y Montoneros. La guerrilla argentina en una encrucijada, La Plata, De la Campana, 2013, 207-226.

30 Ver Di Tella, Guido, Perón-Perón. 1973-1976, Buenos Aires, Hyspamerica, 1986.

31 Baschetti, Roberto, Documentos 1973-1976. De la ruptura al golpe, La Plata, de la Campana, 1999, $237-238$.

32 Idem.
} 
de carácter político: el fin de todas las formas de represión y de las intervenciones sindicales; la vigencia de la democracia sindical; la anulación del pacto social y el llamado inmediato a paritarias; la libertad de los presos políticos; la libertad de expresión; la reorganización del peronismo y el reencauzamiento del proceso de liberación.

La apelación a la resistencia y a las milicias no era algo nuevo en Montoneros. Una y otra nutrieron de manera persistente su imaginario acerca del peronismo revolucionario. ${ }^{33}$ Como en años precedentes, su alusión permitía cuestionar al gobierno sin abandonar la identificación peronista, sino por el contrario, afirmándose como la encarnación de su variante revolucionaria. Montoneros siempre había reconocido el liderazgo de Perón, pero también, una tendencia revolucionaria que lo excedía y de la que había dos antecedentes. Por un lado, el proyecto evitista de 1951 de armar al pueblo mediante milicias, que el propio Perón había desestimado; según la interpretación montonera, debido al cerco creado por los sectores reaccionarios del movimiento. ${ }^{34}$ Por otro lado, la resistencia peronista desde 1955, considerada el inicio efectivo de una trayectoria revolucionaria. $35 \mathrm{El}$ "pasaje a la clandestinidad" de 1974 fue imaginado como una recreación de la resistencia y como la concreción del proyecto de Eva.

El primer número de Evita Montonera, revista que desde su nombre aludía a la líder como la primera montonera, explicitó los términos estratégicos de la clandestinización: se había iniciado una guerra integral en la que se adoptaría una posición defensiva y de retirada para evitar la aniquilación y acumular fuerzas para preparar una futura ofensiva generalizada. El objetivo de un futuro contraataque orbitó constantemente en las definiciones montoneras desde entonces. Sin embargo, la retirada se combinaría con dos tareas principales: la organización y el impulso de prácticas de resistencia para hostigar al enemigo; y la reorganización del movimiento peronista, mediante un partido político liderado por Montoneros que se presentaría a elecciones en 1977. En caso de que las circunstancias políticas impidieran la realización de comicios, se contaría con las milicias peronistas, germen de un futuro Ejército popular. ${ }^{36}$

Esas redefiniciones se tradujeron en modificaciones estructurales: los comandos, con los que habían operado militarmente hasta ese momento, pasaron a ser pelotones, y se diferenció a los combatientes (quienes tenían funciones militares en el Ejército en construcción) de los milicianos (militantes que daban apoyo a los pelotones pero que seguían dedicándose a la realización de actividades políticas). ${ }^{37}$

\footnotetext{
33 Ver Otero, Rocío, "Ante el síndrome de Hamlet: Evita es montonera”, Estudios, № 34, Universidad Nacional de Córdoba, 2015, 101-118 y “Montoneros y la resistencia: identidad política y estrategia de lucha (1970-1980)", Quinto Sol, Vol. 23, No 1, enero/abril, la Pampa, 2019, 1-20.

34 La idea de que Perón se había encontrado cercado por los sectores reaccionarios del peronismo, también fue utilizada por Montoneros durante la segunda mitad de 1973 para dar sentido al enfrentamiento progresivo de Perón con los sectores de la izquierda peronista. Muchas interpretaciones sostienen que en 1973 la "teoría del cerco" fue tan solo un modo de posponer lo que ya era entendido como una ruptura inevitable con el líder.

35 En mayo de 1973, poco después de la victoria de Cámpora, Rodolfo Galimberti había manifestado públicamente que en adelante Montoneros organizaría las milicias de obreros. En respuesta, Perón ordenó su destitución como representante de la juventud ante el Movimiento Peronista.

36 Evita Montonera, № 1, diciembre de 1974, 4-17.

37 Ver Bartoletti, Julieta, Montoneros: de la movilización a la organización, Rosario, Laborde Editor, 2011, 171 y ss.
} 
En enero de 1975 Evita Montonera dio cuenta del desconcierto existente en sus filas acerca de la integración entre las acciones militares y las legales. Por ello, llamó a evitar desviaciones militaristas, politicistas y reivindicativas y a

ligar los tres niveles de nuestra acción en todas las coyunturas: a) la acción reivindicativa de masas; b) la acción política, donde encuadramos en un nivel superior a la acción reivindicativa de masas y orientamos el conjunto de los esfuerzos hacia un mayor poder y organización popular; c) la acción militar, como nivel superior determinante desde el punto de vista estratégico, aunque no sea la actividad principal en algunas coyunturas. ${ }^{38}$

En respuesta a este problema, se establecieron tres objetivos: la construcción de las milicias y del Ejército montonero; el impulso al Partido Auténtico; y el lanzamiento del Bloque Sindical del Peronismo Auténtico.

En primer lugar, en lo que respecta al plano militar, al iniciar el año se anunció el abandono de la posición defensiva mediante el lanzamiento de la $1^{\circ}$ Campaña de ofensiva táctica militar, cuyo objetivo era crear las condiciones de un contraataque y "probar al enemigo que es imposible 'pacificar' al país por la represión". ${ }^{39}$ A mediados del año se anunció la $2^{\circ}$ Campaña. Evita Montonera dedicó una sección, las “Crónicas de la Resistencia”, a informar los atentados llevados a cabo por las milicias contra la policía, los monopolios y la derecha peronista. A la vez, hacia el interior de la organización, en octubre, la Conducción Nacional sancionó un Código de Justicia Penal Revolucionaria que estableció la posibilidad de ser acusado de un conjunto de delitos, la mayoría vinculados a las nuevas estructuras organizativas: la seguridad, el manejo de recursos y la conducta disciplinada. Su aprobación supuso que sumarse a las filas montoneras implicaba un elevado grado de disciplina interna y compromiso e implicó una modificación de las condiciones de incorporación de nuevos militantes: era necesario romper lazos, tener medios de subsistencia propios y una conducta acorde con las indicaciones que transmitía la organización en sus publicaciones. ${ }^{40}$ Para el momento en que se sancionó el código, ya existían tensiones internas y se multiplicaban reclamos sobre la exposición en la que se encontraban los militantes de superficie. Resulta emblemático el caso de la Columna Norte, que solicitó dinero para brindar casas seguras y refugio, y propuso un replanteo de las estructuras. ${ }^{41}$

En segundo lugar, también a partir de marzo de 1975 se avanzó sobre el objetivo de liderar la reorganización del peronismo al promover la creación del Partido Auténtico (PA), que se presentó como una alternativa al peronismo de Isabel. Si bien el PA contó con el auspicio de Montoneros, no se ajustó a su política militar ni se presentó como su partido. Estuvo integrado por distintos sectores, como la Agrupación del Peronismo Auténtico creada como línea interna del Partido Justicialista en 1974; por dirigentes históricos de la resistencia peronista; y por el grupo de gobernadores ligados a la izquierda peronista que

\footnotetext{
${ }^{38}$ Evita Montonera, № 2, enero-febrero de 1975, 31.

39 Ibid., 34.

40 Ver Slipak, Daniela, "Revolución y justicia: Disciplina, delitos y juicios en la revista Evita Montonera”, Lucha armada en la Argentina, Ejercitar la memoria editores, 2013, 136-147.

41 Ver Alderete, Luciano, “El repliegue montonero. Tensiones entre la Columna Norte y la Conducción Nacional", ponencia presentada en Jornadas Interescuelas, 2017.
} 
habían sido destituidos recientemente. ${ }^{42}$ En abril de 1975 el PA se presentó en las elecciones de la provincia de Misiones en lo que constituyó su única participación en comicios. ${ }^{43}$

Siguiendo el modelo del Movimiento Peronista, en agosto el PA impulsó el Movimiento Peronista Auténtico (MPA) y se constituyó en su rama política. Según la prensa montonera, esos esfuerzos por reorganizar al peronismo formaban parte de un fortalecimiento de la retaguardia a nivel de representatividad y significaban el fin de la fractura del peronismo, "la expulsión definitiva de los traidores, y la reorganización del auténtico peronismo, con sus agrupaciones y ramas, con la hegemonía de la clase obrera, y la conducción de MONTONEROS".44

En tercer lugar, hasta fines de 1975 se dio impulso a las reivindicaciones de masas, para lo cual Montoneros coordinó más de doscientas agrupaciones de base y procuró dar impulso a los reclamos de los trabajadores, primero mediante la JTP y luego, tras la fundación del MPA, mediante el Bloque Sindical del Peronismo Auténtico (BSPA), creado en reemplazo de la JTP y como una alternativa a la CGT y las 62 Organizaciones. El BSPA se propuso ser la rama orgánica del nuevo movimiento y contó con una dirección que, a diferencia de la JTP, no estaba necesariamente integrada por militantes Montoneros y respondía a un espacio que se presentaba como más amplio: el del peronismo auténtico. Ante la militancia de las bases durante las jornadas de protesta de junio y julio de 1975 en contra de las medidas económicas del gobierno, durante la segunda mitad del año Montoneros redobló los esfuerzos para organizar agrupaciones obreras. Además del BSPA, que logró éxitos en Buenos Aires, Córdoba y Villa Constitución, participó en la Coordinadora de Gremios, Comisiones Internas y Cuerpos de Delegados en Lucha de Capital y Gran Buenos Aires. Como sostiene Julieta Pacheco, esas experiencias son una evidencia de que tras el pasaje a la clandestinidad Montoneros siguió dedicado a desarrollar frentes de masas y mantener una inserción territorial. ${ }^{45}$

A principios de octubre Montoneros atacó el Regimiento de Infantería Monte 19 (Formosa), en una acción espectacular en términos militares y logísticos. En la "Operación Primicia" murieron guerrilleros y soldados, la mayoría de los cuales eran conscriptos, lo que causó fuerte repercusión pública. Tras el ataque, el PA fue ilegalizado pese a que varios de sus dirigentes condenaron públicamente el asalto. ${ }^{46}$

Al concluir el año las conducciones tuvieron una lectura positiva del accionar de las milicias y los pelotones en la $2^{\circ}$ Campaña ofensiva. Por ello, anunció la creación del Ejército montonero, como superación de todas las expresiones anteriores de peronismo. A principios de 1976, en las vísperas del golpe de Estado, se lanzó la $3^{\circ}$ Campaña militar de ofensiva táctica. 47

\footnotetext{
42 Ver Servetto, Alicia, 73/76, el gobierno peronista contra las "provincias montoneras", Buenos Aires, Siglo XXI Editores, 2010.

43 Ver Andrade, Mariano, "Partido Auténtico", ponencia presentada en IV Jornadas de Sociología, FSOC/UBA, 2000.

44 Evita Montonera, № 6, agosto de 1975, 10.

45 Pachecho, Julieta, “Análisis de la militancia sindical de Montoneros: la juventud trabajadora peronista y sus luchas", e-@latina. Revista electrónica de estudios latinoamericanos, No 50, 2014, 42.

46 Andrade, ob.cit.

47 Gillespie, ob.cit., 293 y ss.
} 
Para Gillespie, si bien tras el pasaje a la clandestinidad Montoneros impulsó tareas militares y al mismo tiempo procuró mantener contacto permanente con las masas, en la práctica fueron dimensiones incompatibles. Los Montoneros "vagaban cada vez a mayor profundidad en la penumbra" que media entre la guerra de guerrillas urbanas y el terrorismo, y comenzaron a actuar con "atolondrado abandono, rayano en el terrorismo practicado al azar", para debilitar y desmoralizar al enemigo. 48

Según Calveiro, los cientos de operaciones militares realizadas durante 1975 sirvieron para unificar a las fuerzas de seguridad en la tarea de desarticular a los grupos armados. Mientras que los intentos por reorganizar el peronismo (estos y los que vendrían) habrían sido meras maniobras de tipo administrativo para resolver las sucesivas crisis políticas. El "organizativismo", que Calveiro delinea como uno de los vicios que asfixiaron la práctica montonera y signaron su derrota política y militar. Para la autora, esos intentos "se presentaban como soluciones milagrosas para los males cada vez más numerosos de la organización". ${ }^{49}$

Ernesto Salas, por su parte, reconoce que el conjunto de acciones realizadas por Montoneros durante el año 1975 es indicativo de una tensión que se va evidenciando entre una política de masas tendiente a sumar adhesiones desde los movimientos sociales y políticos, y la organización de una fuerza militar combatiente. Para Salas, por lo menos hasta el golpe militar "las estructuras políticas de la organización desarrollaron, con diversa suerte, trabajos políticos en los que se imbricaron con el movimiento social existente o generaron ámbitos de organización inéditos" ${ }^{\prime 5}$ La creación posterior del Partido Montonero fue para el autor lo que clausuró definitivamente la relación con los movimientos sociales.

Es indudable que la clandestinización tuvo como correlato -como no podía ser de otra manera en una estrategia de lucha armada urbana- el repliegue de la movilización de masas lograda en 1972/1973, que nunca volvió a replicarse. No obstante, afirmar que Montoneros se dedicó exclusivamente a las armas, abandonó la política, o la redujo a ademanes administrativos, no resulta del todo acertado.

\section{El agotamiento del peronismo, el montonerismo y la crítica de Walsh}

La rápida generalización del terror producto del plan sistemático de represión implementado por el gobierno militar instalado en el poder el 24 de marzo de 1976, empujó al exilio a militantes y personajes comprometidos con proyectos políticos, tanto armados como no armados, que se sumaron a un éxodo forzado ya iniciado en los años previos. ${ }^{51} \mathrm{El}$ golpe de Estado y las formas que adoptó el exilio significaron un cambio drástico en las condiciones de lucha para Montoneros. Como resalta Hernán Confino, el exilio masivo supuso un aumento de la relevancia de las acciones montoneras en el exterior y la creación de una nueva ingeniería institucional a tal efecto; la emergencia de nuevos sentidos políticos

\footnotetext{
48 Ibid., 328.

49 Calveiro, ob.cit., 115.

50 Salas, ob.cit., 89.

51 Ver Jensen, Silvina, “Exilio e Historia Reciente. Avances y perspectivas de un campo en construcción”, Aletheia, $\mathrm{N}^{\mathrm{o}}$ 2, 2001, s/d.
} 
vinculados con la novedosa dimensión transnacional que adoptó la política; y la distinción entre la actividad política en el territorio y la exiliar. ${ }^{52}$

Inicialmente, Montoneros consideró que había comenzado una ofensiva generalizada sobre el campo popular que agudizaba las contradicciones y aclaraba el panorama político y la localización del enemigo. ${ }^{53}$ En el plano militar, se asumió una estrategia de defensa activa y se dirigió el accionar armado a evitar que el enemigo consolidara su poder. En abril, se lanzó la $4^{\mathrm{a}}$ Campaña de Ofensiva Táctica, concebida con anterioridad al golpe.54 En el plano político, en parte debido a la ilegalización del PA, el Consejo Nacional decidió la transformación de Montoneros en Partido Montonero (PM), abandonando así la lucha partidaria por el peronismo. Así, se volvió un partido de cuadros al estilo leninista, organizado en base a los principios del centralismo democrático. Se crearon nuevas estructuras, como el Consejo Ejecutivo y el Congreso Partidario, instancias que elegirían a las conducciones y decidirían las líneas estratégicas. Además, se lanzó el Movimiento Montonero (MM) para reemplazar al peronismo, que planteó la organización del pueblo alrededor de seis ramas: sindical, barrial, juvenil, femenina, campesina y profesional, como espacios de vinculación del partido de vanguardia con las luchas obreras. ${ }^{55}$

La creación del PM y del MM fue una consecuencia directa del diagnóstico que Montoneros hizo del peronismo. ${ }^{56}$ En primer lugar, consideraron que el último gobierno de Perón había fracasado al intentar aplicar "la vieja doctrina justicialista" basada en la alianza de clases. Para Montoneros "la única forma de alcanzar la justicia social total y definitiva está en el cambio de las estructuras capitalistas y su reemplazo por las estructuras socioeconómicas socialistas" ${ }^{57}$ En segundo lugar, consideraron que el gobierno de Isabel había traicionado los valores del peronismo. Finalmente, los propios intentos de construir un peronismo auténtico no habían dado los resultados esperados, en particular, debido a la ilegalización de ese espacio político. Por ello, consideraron que el peronismo estaba agotado históricamente y que el PM sería el instrumento para lograr un salto cualitativo que garantizara el reemplazo de la "conducción estratégica unipersonal" de Perón por la conducción estratégica por parte de una organización, los Montoneros, ante la realidad del peronismo, una "organización burocrática de sellos y sectas". ${ }^{58} \mathrm{El}$ agotamiento del peronismo no significaba la superación de la experiencia de la clase obrera, de sus valores, sus sentimientos y su conciencia política. Por el contrario, la base social sobre la cual el MM esperaba constituirse era la del peronismo y el desafío radicaba en superar sus limitaciones,

\footnotetext{
52 Ver Confino, Hernán, “Entre la articulación y el conflicto. Una aproximación a los itinerarios de los exiliados montoneros en México", Lastra, María Soledad [Comp.], Exilios: un campo de estudios en expansión, CLACSO, Memoria Académica, 2017, 135-155.

53 Ver Wainfeld, Mario y Natanson, José, "Montoneros durante el Proceso", Todo es Historia, No 347, 1996, 8-21.

${ }^{54}$ Gillespie, ob.cit., 358 y ss.

55 Ibid.,, 366 y ss. El Congreso no se reunió durante todo 1976 y alrededor de esa circunstancia giraron los nuevos conflictos internos.

56 Para los avatares de Montoneros respecto del peronismo ver Otero, Rocío, Montoneros y la memoria del peronismo, Buenos Aires, Prometeo, 2019.

57 El Montonero, No11, 24/4/1976, 5.

58 Ibid., 6.
} 
lograr la hegemonía de la clase obrera y desarrollar la identidad política superadora: el montonerismo. 59

Las nuevas definiciones políticas tuvieron correlatos simbólicos. En Evita Montonera se indicó que se asumiría la denominación de "Partido Montonero" "sin ningún tipo de aditamento", y que su consigna sería "Patria o Muerte, Venceremos". Además, se precisaban sus emblemas identificatorios: "un ovalo con una $\mathrm{M}$ adentro para ser difundido en las pintadas" y "un símbolo más completo que sería un óvalo en cuya parte superior va la consigna 'Patria o muerte', en el centro el fusil y la tacuara cruzada, en la parte inferior la palabra Montoneros flanqueda por dos pequeñas estrellas federales, todo sobre un fondo azul y blanco". Por otro, se indicaba que los símbolos y firmas del partido serían: 1) un óvalo con una $\mathrm{M}$ en el centro, con el fusil y la tacuara cruzadas, en la parte superior la palabra "venceremos", en la parte inferior la palabra "Montoneros", y a ambos costados, dos estrellas federales; 2) una estrella federal con las letras " $\mathrm{M}$ " $\mathrm{y}$ " $\mathrm{V}$ " en el centro. El documento indicaba también que la firma de la organización sería la palabra Montoneros completa (en ningún caso "montos") o un óvalo con las letras $\mathrm{M}$ y V en el centro. ${ }^{60}$ Esos símbolos excluían toda referencia a la identificación peronista.

En paralelo a esos esfuerzos políticos, se promovieron acciones armadas e iniciativas que mostraron a Montoneros como una fuerza militar de envergadura. Durante junio y julio de 1976, atentó contra el jefe de la Policía Federal, Cesáreo Cardozo, y contra la Superintendencia de Seguridad Federal, dos operaciones de gran impacto público. Unas semanas después, Horacio Mendizábal, secretario militar de Montoneros, señaló en una conferencia de prensa que la organización no se planteaba el desarrollo de "un Ejército de grandes dimensiones sino una fuerza militar suficiente para hostigar al enemigo" y allanar el camino para la construcción de "una gran fuerza militar popular cuando avancemos en la Contraofensiva". ${ }^{61}$ Poco después, en una entrevista a la revista española Cambio 16, exhibió el arsenal de fabricación montonera, el uso de uniformes y la capacidad logística lograda. La nota reafirmaba que se buscaba crear un ejército para lograr una contraofensiva y "conducir a las masas durante la grave crisis económica que se avecina con estallidos insurreccionales parciales". 62 Además, distinguió a la filosofía peronista del peronismo como identidad de la clase obrera y afirmó: "queremos que el Movimiento Montonero permita la construcción del socialismo en Argentina, cosa que Perón no permitía". ${ }^{63}$

En esa etapa, Montoneros también apostó al plano reivindicativo y realizó esfuerzos por integrar las luchas obreras. En agosto de 1976 impulsó la creación de la CGT en la Resistencia (CGTR), que en su declaración constitutiva se planteó como una herramienta política para unificar y coordinar las luchas del conjunto de los trabajadores desde la clandestinidad, y para organizar la pelea por la recuperación sindical. En su programa de diez puntos se exigía: aumento de salarios; congelamiento de precios; reincorporación de los despedidos; restitución de las leyes laborales suprimidas por la dictadura; vigencia del derecho a huelga; finalización de la intervención de los sindicatos; defensa de las fuentes de

\footnotetext{
59 Evita Montonera, № 14, octubre de 1976, p. 15-16.

60 Ibid., 62-63.

61 Baschetti, Roberto, Documentos 1976-1977. Golpe militar y resistencia popular, Volumen I, La Plata, De la Campana, 2001, 190.

62 Ibid., 138.

63 Idem.
} 
trabajo; cese de la represión al movimiento obrero y al pueblo; vigencia de la libertad de reunión y expresión; y retiro de las fuerzas armadas. ${ }^{64}$ Los objetivos estaban dirigidos exclusivamente a las reivindicaciones específicas de los trabajadores y aunque se llamaba a la construcción de un gran movimiento de liberación nacional para derrotar a la dictadura, nada decía del objetivo socialista y la lucha armada.

A fines de 1976 y principios de 1977 se alzó una voz crítica a las decisiones políticas y estratégicas tomadas por la conducción desde el golpe de Estado: la de Rodolfo Walsh. Por ese entonces oficial segundo, casi duplicaba en edad a los miembros de las conducciones y era respetado por su inteligencia y agudeza entre la militancia. Las observaciones de quien era conocido como "El jefe" o "profesor Neurus" y quien era responsable de la creación de la Agencia Clandestina de Noticias (ANCLA) entre 1976 y 197765, se conocieron públicamente en forma fragmentaria en octubre de 1979 cuando fueron publicados por el grupo disidente "Peronismo Montonero Auténtico". Interesan aquí dos dimensiones de sus planteos: las relativas al diagnóstico de agotamiento del peronismo y a la estrategia armada.

En "Observaciones sobre el documento del Consejo" de noviembre de 1976, Walsh se refirió a la minuta de la reunión de Consejo Nacional de septiembre, la última que tuvo lugar en la Argentina. Allí planteó que la clase obrera estaba retirada, las capas medias derrotadas, los sectores intelectuales y profesionales desbandados, y que se había pronunciado prematuramente el agotamiento del peronismo. Para Walsh era un error "volcar esfuerzos en crear el inexistente Movimiento Montonero" en vez de impulsar la resistencia desde "el existente Partido Peronista": "no hay que crear estructuras al pedo" 66, sentenció.

En el documento "Aporte para la discusión del informe del Consejo" (noviembre de 1977) señaló que había un déficit de formación histórica y teórica que explicaba dos distorsiones. En primer lugar, los ejemplos clásicos de marxismo indicaban que el partido revolucionario lideraría el proceso, pero en el caso argentino el movimiento había generado la vanguardia, razón por la que el PM debía replegarse al peronismo en vez de darlo por agotado y pretender reemplazarlo. En segundo lugar, la aplicación mecánica de la teoría marxista llevaba a inferir que la crisis económica presente sería la crisis definitiva del sistema capitalista:

Naturalmente, si nosotros pensamos que la crisis del capitalismo es definitiva, no nos queda otra propuesta política que no sea el socialismo más o menos inmediato, acolchado en un período de transición, y esa propuesta contribuye a relegar el peronismo al museo. Todos desearíamos que fuera así, pero en la práctica sucede que nuestra teoría ha galopado kilómetros delante de la realidad. Cuando eso ocurre, la vanguardia corre el riesgo de convertirse en patrulla perdida. ${ }^{67}$

\footnotetext{
64 Folleto "Bases para la Unidad Nacional. Declaración Constitutiva de la CGTR".

65 Ver Jozami, Eduardo, Rodolfo Walsh. La palabra y la acción, Buenos Aires, Norma, 2011 y AA.VV., ANCLA. Rodolfo Walsh y la Agencia Clandestina de Noticias (1976-1977), Buenos Aires, Sudestada, 2014.

66 Walsh, Rodolfo, Los papeles de Walsh, s/d, 1979, 10.

67 Ibid., 13. He encontrado un antecedente remoto de la expresión "patrulla perdida" en la película homónima (The Lost Patrol) dirigida por John Ford en 1936, cuya trama gira alrededor de una patrulla inglesa que en el marco de la Primera Guerra Mundial y encontrándose en el desierto, pierde a su oficial al mando.
} 
Walsh consideraba que Montoneros tenía méritos históricos para encabezar una resistencia popular, pero que debía revisar su percepción de la relación de fuerzas para no perder el rumbo. Ello, aclaraba, no significaba que el PM debiera renunciar a "su propuesta intermedia de Movimiento Montonero, su propuesta final del poder socialista, su programa a largo plazo", sino "poner la correcta distancia entre esos objetivos lejanos y la dura realidad actual, que no permite a las masas ni siquiera pensar en el poder, sino en resistir para sobrevivir".68

A principios de 1977, en el documento "Aporte para una hipótesis de resistencia" reflexionó sobre las posibilidades reales de una estrategia de esa naturaleza. Para Walsh, era posible que una vanguardia condujera formas significativas de lucha con algunos centenares de oficiales dispersos en el territorio, siempre que evitara ser aniquilada y contara con recursos, documentación y medios de propaganda. Pero para ello era imprescindible diferenciar la "guerra" de la "resistencia":

La resistencia cuestiona los efectos inmediatos del orden social, incluso por la violencia, pero al interrogarse por el poder, responde negativamente porque no está en condiciones de apostar por él. El punto principal en su orden del día es la preservación de las fuerzas populares hasta que aparezca una nueva posibilidad de apostar al poder. ${ }^{69}$

Walsh recomendaba seguir las líneas de acción "admirablemente teorizadas en la "Correspondencia Perón-Cooke", una línea militar que indicaba evitar acciones indiscriminadas que no se relacionaran "en forma directa e inconfundible" con un interés inmediato de las masas y que impidieran "hacer política en el seno del enemigo o nos quite la bandera fundamental de los Derechos Humanos". ${ }^{70}$ Para Walsh, era necesario enfocarse los "millares de pequeñas victorias", ya que "si las armas de la guerra que hemos perdido eran el FAL y la Energa, las armas de la resistencia que debemos librar son el mimeógrafo y el caño" ${ }^{71}$ De esa forma, Walsh llamó a revisar los lineamientos centrales de Montoneros durante 1976 y advirtió sobre el peligro latente: extraviar el rumbo. Sugería retornar al peronismo y revisar la aplicación errónea del marxismo para no incurrir en estrategias que impidieran tomar conciencia de la situación real. Sus críticas fueron directo al nudo gordiano de Montoneros desde su surgimiento y a lo que, a la vez, es su característica más persistente: la convivencia problemática entre peronismo y marxismo.

Durante el verano de 1977 Roberto Perdía, quien todavía permanecía en el país, sintetizó las conclusiones del Consejo Nacional de octubre y del documento "Balance del 76" en la circular interna $\mathrm{N}^{\mathrm{o}} 4$ fechada el 12 de febrero. Allí parecen haber sido recogidas, al menos parcialmente, parte de las críticas planteadas por Walsh respecto de la posición ante el peronismo. La circular señalaba que bajo la consigna "El peronismo se ha terminado, lo reemplazan los Montoneros" se analizaba mecánicamente la transformación del peronismo:

68 Ibid.. 14.

${ }^{69}$ Idem.

70 Ibid., 19.

71 Idem. 
Se hace hincapié en el objetivo de alcanzar -el montonerismo- y no en la actual situación de masas -su identidad peronista en crisis-. Esta tendencia lleva el germen de una política vanguardista y aislacionista con respecto a las masas, creando condiciones para la fractura y no para la unidad del pueblo. Estas tendencias nacen a partir de la crisis del Movimiento Peronista. Se originan en la débil integración de nuestra lucha con respecto a la práctica y lucha de masas. ${ }^{72}$

El documento advertía sobre "desviaciones" que vinculaba al internismo, al sectarismo, al aparatismo y al militarismo; y delimitaba tres tareas principales: las políticoreivindicativas, las paramilitares y militares, y las organizativas. Se planteaba la necesidad de avanzar en la construcción del Partido y el Ejército, pero también del movimiento, como "la estructura que condensa la historia de lucha e identidad política de nuestro pueblo y que hoy debe conducir su resistencia"; y del frente, como "la alianza necesaria entre pueblo y sectores de la burguesía nacional". ${ }^{73}$ El objetivo socialista perdía peso frente a la revisión del diagnóstico sobre el peronismo y al planteo de una alianza policlasista. En línea con los planteos de Slipak, tanto en la crítica de Walsh como en documentos autocríticos de la conducción (como la circular interna $\mathrm{N}^{0} 4$ ) es posible encontrar elementos de la clave interpretativa de la militarización.

A fines de 1976 Montoneros comenzó a formular propuestas de paz ante autoridades católicas: se dirigieron tres cartas al Episcopado argentino (diciembre de 1976, abril de 1977 y mayo de 1979). En 1978 se elevó un pedido al Vaticano para que interviniera en la pacificación del país.74 Al finalizar 1976, se decidió que las conducciones salieran del territorio argentino, algo que Walsh había incluido en sus sugerencias, cabe suponer que impactado por la desaparición de Roberto Quieto, número dos de la cúpula montonera, en diciembre de $1975 .{ }^{75}$ A juicio Walsh, la detención de personajes emblemáticos podría "infringirnos derrotas decisivas al capturarlos o matarlos". ${ }^{76}$ Aunque muchos análisis afirman que las conducciones desoyeron a Walsh, algunos elementos de la circular $\mathrm{N}^{\mathrm{o}} 4$, las propuestas de paz y la salida de las conducciones, entre otras iniciativas que desarrollaré a continuación, pueden ser entendidas como una respuesta (errónea o no) a sus observaciones.

\section{La vuelta al peronismo: el Movimiento Peronista Montonero}

El 22 de abril de 1977 en una conferencia de prensa en Roma se anunció la creación del Movimiento Peronista Montonero (MPM). Los medios de prensa europeos afirmaron que se trataba de la "confluencia" entre el PM y el MPA, "en la perspectiva de la continuidad

72 Circular Interna No 4, en Gasparini, ob.cit., (Anexo I), 244.

73 Ibid., 245.

74 Gillespie, ob.cit., 384 y ss.

75 Quieto gozaba de una destacada reputación de revolucionario. Su desaparición (que fue seguida de otras detenciones) impactó fuertemente hacia el interior de Montoneros, cuyas conducciones, tras impulsar una campaña solicitando su paradero, decidieron condenarlo a muerte por el delito de "delación bajo tortura" en virtud de sus normas internas vigentes. Quieto permanece desaparecido. Al respecto ver Vignollés, Alejandra, Doble condena. La verdadera historia de Roberto Quieto. Secuestrado por los militares y acusado de traición por los montoneros, Buenos Aires, Sudamericana, 2011.

76 Walsh, ob.cit., 14 
y la superación del peronismo". ${ }^{77}$ En boca de Mario Firmenich se dio a conocer un "Programa de pacificación nacional para la constitución de un Frente de Liberación Nacional y Social" y se entregó a la prensa internacional el documento "Ocho puntos de Roma", síntesis de las exigencias: libertad de los presos políticos; reconocimiento de los partidos; condena a los responsables de torturas masivas; reintegración de la CGT, los sindicatos intervenidos y la legislación laboral; convocatoria a elecciones generales para la designación de autoridades; renuncia del ministro de Economía y restauración de los derechos civiles.78 Las reivindicaciones del MPM no mencionaban ninguna vocación socialista ni referían a la lucha armada. En cambio, ponía el eje en la denuncia humanitaria, la restitución del normal funcionamiento democrático y la crítica a la política económica de la dictadura militar.

La apuesta por el MPM supuso destinar esfuerzos políticos hacia el extranjero. La organización logró presencia en algunas agrupaciones de exiliados como el Comité de Solidaridad con el Pueblo Argentino (México), el Comité Argentino de Información y Solidaridad (Francia) y los Comités de Solidaridad con los Familiares de Presos y Desaparecidos (COSOFAM) ${ }^{79} \mathrm{El} \mathrm{MPM}$ declaró querer entablar "relaciones fraternales con organizaciones revolucionarias y movimientos de liberación nacional" debido a la necesidad de "combate conjunto contra el sionismo, el racismo, el apartheid y el neocolonialismo". ${ }^{80}$ De ese modo, su lucha era enmarcada en las luchas del Tercer Mundo por la liberación.

Las actividades de la Rama Femenina y su labor en materia de derechos humanos y solidaridad con presos y desaparecidos en la Argentina son un buen ejemplo de las nuevas iniciativas. Desde las páginas de su boletín, se denunciaron desapariciones, violaciones sistemáticas de derechos humanos, se exigió la publicación de las listas de detenidos y se denunció la existencia de niños secuestrados. ${ }^{81}$ En Israel existió una comisión específicamente conformada por viudas de guerrilleros argentinos que se sumó a la campaña montonera. ${ }^{82}$ En septiembre de 1978 Adriana Gauda, responsable de la oficina del MPM en Beirut, expresó en una entrevista para la revista Proceso de México que el MPM trabajaba en México, Colombia, Venezuela, España, Italia, Gran Bretaña, Francia, Suecia, Beirut y Tanzania, que cubría América Latina, Europa, Escandinavia, Medio Oriente y África. Y que esperaba instalar oficinas en Angola, Mozambique, Chipre e Iraq. También señaló que "este trabajo internacional es un trabajo complementario de la lucha que se desarrolla dentro del país, y que es lo prioritario y estratégico". 83 Según Silvina Jensen, Montoneros quiso capitalizar la movilización de familiares de desaparecidos contra la dictadura, como una fuerza susceptible de ser activada a favor el proyecto político

77 "Presentación en Roma del Movimiento Peronista Montonero", El País, 22/4/1977, Madrid, disponible en https://elpais.com/diario/1977/04/22/internacional/230508018_850215.html.

78 El Descamisado edición Centroamérica, No 1, mayo de 1977, 1.

79 Ver Acha, Omar, La nación futura. Rodolfo Puigrrós en las encrucijadas argentinas del Siglo XX, Buenos Aires, EUDEBA, 2006, 260-288.

80 Vencer, Año 1, No 1, 1979, s/d, 4.

81 Ver boletín de la Rama Femenina del MPM, 1979, s/d.

82 Robledo, Pablo, Montoneros y Palestina. De la revolución a la dictadura, Buenos Aires, Planeta, 2018, 171 y ss.

83 Proceso, No 98, México DF, 16/9/1978. Cit. en Robledo, ob.cit., 203. 
montonero ${ }^{84}$, aunque otros análisis, como el de Gillespie, afirman precisamente lo contrario. 85

En el plano militar, el 15 de marzo de 1978 se conoció el decreto 001/78 sobre la “Implementación y utilización de uniformes e insignias del Ejército Montonero y las milicias montoneras". Muchas interpretaciones cifran en ese reglamento un nuevo síntoma de militarismo. Calveiro presta particular atención a ese reglamento, que define como la expresión más formal y exagerada de la intención de construir un ejército, aunque a su juicio, fue lo superfluo ocupando un lugar central. ${ }^{86}$ En contraste, llama la atención que la autora confunda el MM con el MPM en los pocos renglones que le dedica al tema. ${ }^{87}$ Para Gasparini, el reglamento fue una manifestación del "desvarío militar y el extravío triunfalista de la conducción nacional" ${ }^{88}$ En los considerandos del decreto se afirmaba que la representatividad montonera:

...se ha incrementado a partir de la heroica resistencia de nuestro pueblo, que orientada y encabezada por nuestro Partido, nuestro Ejército y el Movimiento Peronista Montonero, ha coronado con éxito la maniobra de Defensa Activa e hizo detener la ofensiva del enemigo. Que, por ello, nuestras fuerzas están ahora en condiciones de comenzar a ejecutar una nueva maniobra consistente en la preparación de la contraofensiva popular contra la dictadura. ${ }^{89}$

En efecto, si bien durante todo el año 1978 Evita Montonera anunció en sus tapas el "año de organización del MPM", a la par, las conducciones exhibieron públicamente la consolidación de Montoneros como Ejército y su intención de protagonizar una contraofensiva, objetivo que, es necesario repetirlo, nunca desde el pasaje a la clandestinidad declinó su presencia en el discurso oficial. En el nuevo contexto, el énfasis en la contraofensiva se basaba en la idea de que Montoneros había acrecentado su representatividad tras impulsar durante todo 1977 diversas formas de resistencia obrera contra la dictadura, aunque voces disonantes contradecían esa apreciación. Algunos testimonios afirman que ya en noviembre de 1977 en una reunión clandestina en España para ampliar el Consejo Superior del MPM, militantes recién llegados a Europa comunicaron a las conducciones que creían que en el país abundaba la aniquilación, el repliegue y apenas una lucha por la supervivencia. ${ }^{90}$

Para 1978, la organización no solo estableció nuevos reglamentos para sus tropas. Además, contaba con arsenales de fabricación propia, presencia en Beirut, estrechos vínculos con la Organización para la Liberación de Palestina y su facción armada, Al Fatah;

84 Jensen, Silvina, La lucha por los derechos humanos durante la dictadura, Buenos Aires, Sudamericana, 2010, 116 y ss.

85 Gillespie, ob.cit., 384.

86 Calveiro, ob.cit., 92.

87 Ibid., 116.

88 Gasparini, ob.cit., 261.

89 Documento disponible en ibid., 261-266.

${ }_{90}$ Anguita, Eduardo y Caparrós, Martín, La voluntad. Una historia de la militancia revolucionaria en la Argentina. 1976-1978, Buenos Aires, Booket, 2009a, 514 y ss. 
y un acuerdo para fabricar explosivos en el sur del Líbano, a cambio de campos de entrenamiento, instructores y misiles RPG7.91

En el marco del Mundial de Fútbol a realizarse en la Argentina, se lanzó la "Campaña de ofensiva táctica Mundial '78". El órgano de prensa del Ejército montonero detalló indicaciones e informó que la "heroica resistencia de los trabajadores y el pueblo argentino había agotado la ofensiva criminal de la dictadura" y que ahora había que forzarla a una retirada, para poder lanzar una contraofensiva. Para ello se lanzaba una "ofensiva táctica integral, es decir, política, militar y propagandística". 92 En ese marco, Montoneros protagonizó atentados sin víctimas y acciones de denuncia contra la dictadura, como la interferencia de señales de televisión con mensajes mediante instrumentos como "Radio Liberación", una práctica alternativa de comunicación basada en un sistema de transmisores que interceptaban señales de televisión y transmitían mensajes, otro esfuerzo comunicacional de la época. ${ }^{93}$ En las directivas para el desarrollo de lo que fue pensado como una campaña de denuncia contra la dictadura, se informó que estaba "terminantemente prohibido" realizar operaciones que afectaran partidos, equipos o delegaciones extranjeras, periodistas, turistas y espectadores ${ }^{94}$, otro indicio de una modificación en las características del accionar militar tendiente a evitar los "desvíos" militaristas.

A pesar de que el lanzamiento del MPM buscaba ser una revalorización del peronismo, existió una tensión entre el "montonerismo" y el peronismo que quedó plasmada en boletines, publicaciones y documentos internos. Como un dato indicativo, los que correspondían al MPM o a sus distintas ramas exhibían un escudo combinado conformado por el escudo montonero (la $M$ rodeada de una lanza tacuara y un FAL cruzados) y el escudo peronista. Ese escudo combinado, símbolo de la fusión entre montonerismo y peronismo, nunca apareció en Evita Montonera y en Estrella Federal, publicaciones oficiales del Partido y el Ejército montoneros.

La dualidad entre peronismo y montonerismo no fue ajena a muchos de los miembros del MPM, algunos de los cuales consideraron que el PM hegemonizaba organizativa y burocráticamente el movimiento. Al renunciar al Consejo Superior, Arnaldo Lisazo afirmó en una carta que su decisión se fundaba en que el MPM,

...no tiene vida propia, sino que existe como una mera herramienta del Partido Montonero. El 80\% de los integrantes del Consejo pertenecen al Partido Montonero, porcentaje que se mantiene o acrecienta en la Mesa Ejecutiva. Esto demuestra que el MPM se limita a ejecutar la política del Partido. También demuestra la imposibilidad de modificarla desde el Movimiento. Esto teóricamente es valedero, pero si consideramos que a su vez el Partido está conformado como Ejército, aunque sea con el nombre de Partido o Movimiento, con desconocimiento total de los miembros de este

91 Ver Robledo, ob.cit.

92 Estrella Federal, № 4, abril de 1978, 3.

93 Ver Vinelli, Natalia, Radio Liberación TV. Comunicación, agitación y propaganda para la Contraofensiva montonera en años de dictadura militar, tesis de grado, FSOC/UBA, 2017.

94 Estrella Federal, No , abril 1978, 3-4. 
último, amparándose en el secreto militar. Perdóneseme la expresión pero me viene a la memoria una frase del militarismo clásico: subordinación y valor. ${ }^{95}$

La percepción que recoge esa carta está presente en muchos otros testimonios e interpretaciones. Según Gillespie, el lanzamiento del MPM fue un retroceso en busca de apoyo en una organización de masas arraigada en los más amplios sectores populares, que contaría con los "peronistas auténticos". Aunque en la práctica, el verdadero poder habría estado en manos de las jerarquías del Partido y el Ejército, que controlaban la tesorería bélica y los puestos relevantes de las secretarías del MPM. ${ }^{96}$ Pese a lo acotado y confuso de sus alusiones al MPM, Calveiro no duda en afirmar que se redujo a la aparición pública en el exterior de militantes que ya pertenecían a la organización pero que "no representó la realización de alianzas o acuerdos con otros sectores que ampliaran la base de sustentación". 97

Sin embargo, existen percepciones variadas sobe la significancia del MPM. Gregorio Levenson, su tesorero, vincula la iniciativa con la necesidad de contar con nueva estructura que permitiera a Montoneros operar en el exterior tras la salida del país de las conducciones. Para Levenson, ...se trataba de una organización menos ortodoxa, que permitía captar a peronistas que participaban de algunas tareas de superficie y diferenciarlos de los que figuraban como miembros del Partido y el Ejército montoneros. ${ }^{98}$

De allí que se lanzara una convocatoria amplia, que incluyó a los ex gobernadores Oscar Bidegain y Ricardo Obregón Cano y a intelectuales y artistas como Rodolfo Puiggrós y Norman Brisky. Como sostiene Mariano Pacheco, la distribución de cargos, que dejó como secretario general a Firmenich, respondía al objetivo de impulsar la identidad montonera, pero la presencia de dirigentes históricos del peronismo buscaba brindar referencias políticas a los trabajadores, pese a que su alcance fue muy limitado e incluso nulo en el interior del país. ${ }^{99}$ Perdía reconoce que la incidencia organizativa y política del MPM dentro del país fue débil, pero resalta que se constituyó "en un importante referente internacional. En un valioso instrumento para fortalecer la solidaridad y el apoyo internacional". ${ }^{100}$ En efecto, los primeros ministros de Suecia y España, el presidente de Francia, el secretario de la Internacional Socialista, y otros líderes y autoridades recibieron a los miembros del Consejo Superior del MPM y promovieron acuerdos. ${ }^{101}$

\section{La Contraofensiva}

El llamado a los trabajadores a protagonizar una resistencia, la iniciativa de reorganización del peronismo y los pedidos de paz, parecen contradictorios

\footnotetext{
95 Cit. en Larraquy, Marcelo, Fuimos Soldados, Buenos Aires, Aguilar, 2006, 137.

96 Gillespie, ob.cit., 372 y ss.

97 Calveiro, ob.cit., 93.

98 Levenson, ob.cit., 206.

99 Pacheco, Mariano, Montoneros silvestres. Historias de resistencia a la dictadura en el sur del conurbano, Buenos Aires, Planeta, 176.

100 Perdía, 2013, ob.cit., 515.

101 Gillespie, ob.cit., 385 y ss.
} 
retrospectivamente con la decisión anunciada a fines de 1978: el lanzamiento oficial de la Campaña Contraofensiva Estratégica Comandante Carlos Hobert" (CE).102 Las tapas de los últimos números de Evita Montonera (23, enero de 1979; 24, mayo de 1979 y 25, agosto de 1979) pasaron a anunciar el "Año de la Contraofensiva popular". Muchos testimonios (incluso de quienes luego protagonizaron disidencias) reconocen que fue aprobada por unanimidad. 103

Poco después de lanzada, el 27 de abril de 1979, tuvo lugar la primera huelga general contra la dictadura. Ello, junto a algunos conflictos sindicales de cierta envergadura fueron interpretados como "indicadores del cambio de naturaleza de la movilización sindical". ${ }^{104}$ Más aún, tal como afirmó Firmenich en una entrevista, como una respuesta del movimiento obrero al llamado montonero "Resistir es vencer" que "ha masificado la resistencia y ha llevado al fracaso a la política recesiva". ${ }^{105}$

Si bien incluyó acciones militares, la CE fue una operación pensada como un disparador del descontento obrero y se basó en la idea de que Montoneros había logrado constituirse en una verdadera vanguardia del proletariado: "Los planteos de la CGT en la Resistencia y las estructuras políticas de los montoneros, fueron asumidos, progresivamente, por la casi totalidad del movimiento obrero" se afirmó en la recién lanzada revista internacional del MPM. ${ }^{106}$ Esas apreciaciones expresaban la importancia central que se le otorgaba a la reivindicaciones obreras en la lucha contra la dictadura. En efecto, poco después de la huelga de abril, una comitiva de representantes de la rama sindical del MPM concurrió a la reunión anual de la Organización Internacional del Trabajo en apoyo a los trabajadores argentinos. 107

La lectura montonera sobre la movilización existente en la Argentina se amalgamó con una percepción acerca de las dos experiencias revolucionarias que signaron el año 1979. Desde Evita Montonera se afirmó:

En el mismo año en que nosotros iniciamos la contraofensiva popular nuestros hermanos nicaragüenses, bajo la conducción estratégica del Frente Sandinista de Liberación Nacional, finalizaban su ofensiva insurreccional contra la dictadura ya legendaria y aparentemente inamovible de la familia Somoza. En este mismo año se produjo la insurrección iraní que acabó completamente con la dinastía imperial de los Palevi. (...) Hay una razón de fondo que explica las actuales revoluciones populares en diversas partes del mundo: la crisis mundial del imperialismo lo pone en una situación de debilidad relativa en la que ya no puede, como lo hacía hace algunas décadas, intervenir militarmente como gran gendarme. ${ }^{108}$

Como puede verse, en los fundamentos de la CE resonaba la convicción sobre la crisis definitiva del sistema capitalista, que ahora parecía quedar probada por el éxito de

102 Evita Montonera, №22, septiembre/octubre de 1978, 13.

103 Levenson ob.cit., 215; Bonasso, Miguel, Lo que no dije en "Recuerdo de la muerte", Buenos Aires, Sudamericana, 2014,60 .

104 Vencer, $\mathrm{N}^{\mathrm{o}} 1, \mathrm{~s} / \mathrm{d}, 3$.

105 Ibid., 4.

106 Ibid., 14.

107 Gillespie, ob.cit., 394-395.

108 Evita Montonera, № 25, agosto 1979, 3-4. 
otros procesos revolucionarios del Tercer Mundo, en algunos de los cuales, Montoneros tuvo una participación directa. En marzo de 1979 y como parte sus iniciativas desde el exterior, por ejemplo, impulsó en Costa Rica Radio Noticias del Continente, una radio de onda corta que se puso a disposición de movimientos revolucionarios del continente y tuvo un rol destacado en la revolución sandinista. ${ }^{109}$

La CE tuvo tres tramos: concentración, aproximación y ataque. El primero se desarrolló entre noviembre de 1978 y abril de 1979, y con tal fin se impulsaron convocatorias en México y España para reclutar militantes, que recibieron entrenamiento en México, Siria y Líbano. Confino ha puesto en evidencia que los militantes que participaron de la CE y sobrevivieron tienen recuerdos contradictorios. Algunos sostienen que lo decidieron en forma voluntaria porque consideraron que tenían una obligación moral con la organización y sus compañeros muertos y desaparecidos. Otros, que se sintieron obligados por sus superiores. ${ }^{110}$

La CE se llevó a cabo en dos fases, a principios de 1979 y a principios de 1980. La primera de ellas consistió en diversas operaciones llevadas a cabo por las Tropas Especiales de Agitación (TEA) al mando de Raúl Yagër, Secretario militar del Ejército montonero, para promover un clima de movilización y agitación callejero mediante transmisiones clandestinas y la inserción en grupos de trabajadores movilizados; y las Tropas Especiales de Infantería (TEI) al mando de Mendizábal, que se ocuparían de realizar atentados militares exclusivamente contra miembros del equipo económico. ${ }^{111}$ Por un lado, se pondría énfasis en acciones reivindicativas, clandestinas y sin uso de la fuerza. Por otro, se llevarían a cabo acciones armadas, pero ya no indiscriminadas, como en las campañas ofensivas de los años anteriores, otro indicador de un intento de evitar sesgos militaristas. Los blancos respondían a una impugnación al plan económico de la dictadura militar.

En los recuerdos de algunos militantes de las TEA persiste la imagen de un desengaño ante la falta de acompañamiento popular: "cuando regresó de su gira por los barrios", reconstruye Marcelo Larraquy, Lazarte sintió que "no tenía sentido pasar los discursos de Firmenich hablando de la toma del poder si después tenían que salir corriendo" y que "las transmisiones no los integraban a la resistencia obrera frente a la dictadura ni tampoco eran un elemento disparador de la insurrección popular". ${ }^{112}$ Según reconstrucciones, el propio Yager, tras pasar varios meses en la Argentina al mando de las TEI, habría informado que en el país no había apoyo popular.113

La segunda fase de CE preveía la utilización de armas que las tropas TEI habían dejado ocultas en Buenos Aires antes de salir del país en 1979, pero esas armas fueron descubiertas por las fuerzas represivas. Entre febrero y marzo de 1980 fueron secuestrados

109 Ver Esperón Rodríguez, Carlos, “Montoneros en Costa Rica. Radio Noticias del Continente, contrainformación y lucha armada", Avatares, No 12, Buenos Aires, 2016, 1-10.

110 Ver Confino, Hernán, “Tensiones de un retorno: la Contraofensiva Estratégica Montonera de 1979 y 1980 en Argentina", Revista Izquierdas, № 28, 2016, 274-291.

111 Hubo tres grandes atentados: a fines de septiembre, contra la casa de Guillermo Walter Klein, a cargo de la Secretaría de Programación y Coordinación Económica; en noviembre, contra el Secretario de Hacienda, Juan Alemann; pocos días después, contra el empresario Francisco Soldati. El atentado contra Soldati fue el único llevado a cabo por las TEI que logró su objetivo y también el único que concluyó con muertes de las filas montoneras. Ver Larraquy, ob.cit., 155-174.

112 Ibid., 88.

113 Ibid., 177. 
los miembros del grupo que iban ingresando al país o que estaban por ingresar. Hacia junio de 1980 ya habían sido secuestrados o asesinados la mayoría de los miembros de la segunda contraofensiva. ${ }^{114}$

En septiembre de 1979 la Argentina recibió la visita de la Comisión Interamericana de Derechos Humanos (CIDH), en respuesta a los reclamos impulsados por las agrupaciones de exiliados políticos. Según Jensen, uno de los recursos utilizados por la dictadura para crear un clima contrario a la misión de la comisión, fue reavivar "el fantasma subversivo" y comunicar en forma exagerada y sensacionalista las acciones militares de las tropas montoneras, con el fin de mostrar que quienes recientemente habían sido denunciados como desaparecidos, eran en realidad subversivos que se ocultaron en el país o se habían ido y habían vuelto para desestabilizar al gobierno por la vía de la violencia. ${ }^{115}$ Según Jensen, las dudas y polémicas invadieron el exilio, que se interrogó por la auténtica conversión (o no) hacia una "lógica político-humanitaria" de los Montoneros. Para la autora, a la hora de implicarse en algún acontecimiento que podía funcionar como "test de humanitarismo" se desataban polémicas, como sucedió con la denuncia de los campos de reclusión psiquiátrica en la URSS o las denuncias de violaciones de derechos humanos por los gobiernos cubano y chino. Para Jensen, la aceptación o rechazo de la convocatoria de la CE fue uno de esos temas: la lógica del enfrentamiento, el imaginario y el lenguaje militar parecía contradecir la denuncia de violaciones a derechos humanos cuando esos mismos militantes eran víctimas. 116

Alrededor de la decisión de lanzar la CE primero; y de la lectura que hicieron las conducciones de la primera fase de la operación luego; se produjeron las dos rupturas que signaron el ocaso montonero: el Peronismo Auténtico y los Montoneros 17 de octubre. ${ }^{117}$ Ambas disidencias exaltaron al peronismo, lo propusieron como el espacio de activación política y afirmaron tener como objetivo final la construcción de una sociedad socialista. De esa forma, se reproducía la contradicción esencial del fenómeno montonero entre peronismo y socialismo, quedando las críticas reducidas, al menos en apariencia, a un problema de conducción.118 Sostiene Confino que "ambas disidencias imprimieron su propia lectura de la trayectoria de la organización y del accionar de sus dirigentes" para "legitimar sus

114 En el año 2003 en el marco del juicio contra miembros del Batallón 601, grupo tareas a cargo de la desarticulación de la CE, el juez Claudio Bonadío acusó a los tres sobrevivientes de la conducción, Firmenich, Perdía y Fernando Vaca Narvaja como partícipes necesarios del secuestro y homicidio de los participantes de la CE. Narvaja y Perdía estuvieron varios meses en prisión por esta causa, mientras que Firmenich logró eludir el encierro al escapar de la Interpol en España, donde reside. La medida fue ampliamente cuestionada como un "mamarracho judicial" y poco después fue ordenada la liberación de los detenidos. Ver Zúcker, Cristina, El tren de la victoria. La saga de los Zúker, Buenos Aires, Del Nuevo Extremo, 2010, 310 y ss. En general, el fracaso de la $\mathrm{CE}$ es atribuido a los errores de la conducción, pero es necesario enfatizar que su fracaso debe ser evaluado a la luz del accionar exitoso del Batallón 601. Ver Fernández Barrio, Facundo, “El servicio Exterior argentino en la represión a la Contraofensiva de Montoneros en Basil (1978-1980)”, D`Antonio, Débora [Comp.], en Violencia, espionaje y represión estatal. Seis estudios de caso sobre el pasado reciente argentino, Buenos Aires, Imago Mundi, 2018, 93-118.

115 Jensen, 2010, ob.cit., 168.

116 Ibid., 185.

117 Ver Slipak, Daniela, "Comunicar la disidencia. Un recorrido por tres escisiones de Montoneros en los setentas", Izquierdas, No 14, Santiago de Chile, 2018, 141-161.

118 Ver "Una carta polémica”, firmada por Rodolfo Galimberti y Juan Gelman y "Montoneros 17 de octubre: una naciente fuerza política", firmada por Miguel Bonasso, Jaime Dri, Ernesto Jauretche y otros. 
flamantes espacios políticos". 119 En esos planteos críticos de una porción de sus militantes, también es posible encontrar elementos de lo que luego serán claves de lectura recurrentes sobre Montoneros.

Al concluir la CE y tras esas rupturas, la conducción anunció el fin de la lucha armada. Aunque durante varios años se siguieron impulsando iniciativas políticas (el MPM se disolvió recién en diciembre de 1983) y Montoneros tomó postura sobre acontecimientos clave del período, como la Guerra de Malvinas y el inicio de las movilizaciones en los primeros años del gobierno de Raúl Alfonsín una vez recuperada la democracia; resta producir conocimiento al respecto.

\section{Conclusiones}

En este artículo he intentado poner en evidencia que pese a la decisión de pasar a la clandestinidad en 1974 e iniciar el proceso de conformación de un Ejército, junto al accionar militar, entre 1974 y 1980 Montoneros impulsó gran cantidad de iniciativas políticas y reivindicativas de una riqueza, variedad y dinamismo invisibilizada por la hegemonía de la clave de lectura de la militarización.

En efecto, existieron múltiples derivas (y no solo la militar) en la evolución de este grupo político. Aunque erróneos, desacertados o ajenos a la realidad del país, existieron esfuerzos por consolidarse a nivel político, primero intentando liderar el peronismo; luego, al pretender reemplazarlo; para más tarde procurar reorganizarlo y fundirlo al montonerismo.

Asimismo, Montoneros invirtió esfuerzos para potenciar diversas reivindicaciones, como las de los obreros y las organizaciones de derechos humanos, del mismo modo que insistió públicamente y en foros internacionales en la necesidad de restituir la democracia y las garantías constitucionales en la Argentina. Esas múltiples derivas estuvieron atravesadas por dilemas: sin dudas, los factores militares y los políticos se mostraron muchas veces contradictorios o en tensión. Pero, lejos de producirse una síntesis que hipertrofió lo militar y atrofió lo político, se siguieron intentando reajustes, revisiones y nuevas estrategias al calor de cada coyuntura.

La mayor parte de esos esfuerzos han sido poco analizados por la bibliografía o, más aún, permanecen directamente desatendidos. Solo recientemente, esas experiencias comienzan a ser paulatinamente revisitadas con novedosas preguntas y perspectivas de análisis. En la experiencia montonera late una rica agenda de temas de investigación pendientes. Así, concluiré con cuatro breves reflexiones en este sentido.

En primer lugar, resulta necesario repensar el lugar que se le otorga a la fase de movilización de masas de 1972/1973 como parámetro de análisis de la totalidad del fenómeno montonero.

En segundo lugar (y vinculado a lo anterior), es necesario poder tomar distancia crítica de las miradas "nativas", construidas por los actores en la época (entre los grupos disidentes, en los propios documentos autocríticos de las conducciones) a la hora de adentrarse en el análisis de esta experiencia contestataria.

119 "La Contraofensiva de Montoneros es un gran tabú de los años setenta", Perfil, 24/3/2019. 
En tercer lugar, muchos de los múltiples ensayos políticos que tuvieron lugar entre 1974 y 1980 y que este artículo ha sistematizado, no han merecido atención salvo las menciones generales presentes en la obra de Gillespie, comúnmente reproducidas en los trabajos posteriores: las experiencias del PA y el MPA; la fundación del PM, el MM y la CGTR durante 1976; la organización del MPM y sus múltiples y variadas iniciativas en el exterior; el tránsito de una lógica de lucha revolucionaria a una humanitaria; las características políticas de la CE. De allí se abren nuevas líneas de investigación, algunas de las cuales se encuentran actualmente en expansión, como la que analiza el impacto del exilio en la dinámica política montonera o las características peculiares del montonerismo como identidad política.

Finalmente, el período posterior a 1980 permanece aún en las sombras, de forma tal que poco se conoce sobre el derrotero de la organización madre y sus conducciones tras dar por finalizada la lucha armada; y de los dos grupos escindidos en 1979 y 1980.

Aquí es en donde se pone de relieve que, más de treinta años después de que la obra de Gillespie sentara las bases de una cronología y análisis sobre Montoneros, se deben revisar a contrapelo muchos de los análisis y claves interpretativas consagradas, sobre las que, a veces en forma no consiente, las investigaciones han ido produciendo una acumulación de saberes. Parafraseando a Bachelard, se producen nuevos conocimientos en contra de los saberes establecidos. El conocimiento no solo avanza como el producto del hallazgo de nuevas fuentes, sino también, como consecuencia de la capacidad de mirar lo mismo, de otro modo.

Bibliografía

-AA.VV., ANCLA. Rodolfo Walsh y la Agencia Clandestina de Noticias (1976-1977), Buenos Aires, Sudestada, 2014.

-Acha, Omar, La nación futura. Rodolfo Puigrrós en las encrucijadas argentinas del Siglo XX, Buenos Aires, EUDEBA, 2006.

-Alderete, Luciano, "El repliegue montonero. Tensiones entre la Columna Norte y la Conducción Nacional", ponencia presentada en Jornadas Interescuelas, 2017.

-Amorín, José, Montoneros: la buena historia, Buenos Aires, Catálogos, 2005.

-Andrade, Mariano, "Partido Auténtico", ponencia presentada en IV Jornadas de Sociología, FSOC/UBA, 2000.

-Anguita, Eduardo y Caparrós, Martín, La voluntad. Una historia de la militancia revolucionaria en la Argentina. 1974-1976, Tomo IV, Buenos Aires, Booket, 2009

La voluntad. Una historia de la militancia revolucionaria en la Argentina. 1976-1978, Tomo V, Buenos Aires, Booket, 2009a.

-Bachelard, Gastón, La formación del espíritu científico, México, Siglo XXI, 2000.

-Bartoletti, Julieta, Montoneros: de la movilización a la Organización. Un caso paradigmático de militarización, tesis de doctorado, UGS, 2010.

Montoneros: de la movilización a la organización, Rosario, Laborde Editor, 2011.

-Bonasso, Miguel, Lo que no dije en "Recuerdo de la muerte", Buenos Aires, Sudamericana, 2014, 60 .

-Calveiro, Pilar, Política y/o violencia. Una aproximación a la guerrilla de los años 70, Buenos Aires, Verticales de Bolsillo, 2008 
-Carnovale, Vera, "Más allá de la militarización: la violencia revolucionaria, esperanza y promesa de emancipación", Pasado abierto, N 2451, 2015, 121-142.

-Caviasca, Guillermo, "Los Montoneros y el enfrentamiento con Perón”, en Dos caminos. PRT-ERP y Montoneros. La guerrilla argentina en una encrucijada, La Plata, De la Campana, 2013, 207-226.

-Confino, Hernán, “Tensiones de un retorno: la Contraofensiva Estratégica Montonera de 1979 y 1980 en Argentina", Revista Izquierdas, № 28, 2016, 274-291.

"Entre la articulación y el conflicto. Una aproximación a los itinerarios de los exiliados montoneros en México", en Lastra, María Soledad [Comp.], Exilios: un campo de estudios en expansión, CLACSO, Memoria Académica, 2017, 135-155.

"La Contraofensiva de Montoneros es un gran tabú de los años setenta", Perfil, 24/3/2019.

-Di Tella, Guido, Perón-Perón. 1973-1976, Buenos Aires, Hyspamerica, 1986.

-Esperón Rodríguez, Carlos, "Montoneros en Costa Rica. Radio Noticias del Continente, contrainformación y lucha armada, Avatares, No 12, Buenos Aires, 2016, 1-10.

-Fernández Barrio, Facundo, "El servicio Exterior argentino en la represión a la Contraofensiva de Montoneros en Basil (1978-1980)", en D`Antonio, Débora [Comp.], Violencia, espionaje y represión estatal. Seis estudios de caso sobre el pasado reciente argentino, Buenos Aires, Imago Mundi, 2018, 93-118.

-Franco, Marina, Un enemigo para la nación. Orden interno, violencia y "subversión", Buenos Aires, FCE, 2012.

-Gasparini, Juan, Montoneros. Final de cuentas, La Plata, De la Campana, 2008.

-Gil, Germán, La izquierda peronista, Buenos Aires, Prometeo, 2019.

-Gillespie, Richard, Soldados de Perón. Historia crítica sobre los Montoneros, Buenos Aires, Sudamericana, 2008.

-Grassi, Ricardo, El Descamisado. Periodismo sin aliento, Buenos Aires, Sudamericana, 2015.

-Jauretche, Ernesto, Violencia y política en los 70. No dejés que te la cuenten, Buenos Aires, Ediciones del Pensamiento Nacional, 1997.

-Jensen, Silvina, "Exilio e Historia Reciente. Avances y perspectivas de un campo en construcción", Aletheia, No 2, 2001, 1-22.

La lucha por los derechos humanos durante la dictadura, Buenos Aires, Sudamericana, 2010.

-Jozami, Eduardo, Rodolfo Walsh. La palabra y la acción, Buenos Aires, Norma, 2011.

-Larraquy, Marcelo, Fuimos Soldados, Buenos Aires, Aguilar, 2006.

-Levenson, Gregorio, De los bolcheviques a la gesta montonera. Memorias de nuestro siglo, Buenos Aires, Colihue, 2000.

-Mangiantini, Martín "Los estudios sobre la lucha armada y las organizaciones políticomilitares en los años setenta. Hacia un balance historiográfico de su producción reciente (2001-2015)", en Estudios, No 34, Córdoba, 2015, 79-99.

-Nahmías, Gustavo, La batalla peronista. De la unidad imposible a la violencia política (Argentina 1969-1973), Buenos Aires, Edhasa, 2013.

-Otero, Rocío, "Ante el síndrome de Hamlet: Evita es montonera", Estudios, $N^{\circ}$ 34, Universidad Nacional de Córdoba, 2015, 101-118

"Montoneros y Perón ¿un diálogo de sordos? Apostillas sobre el socialismo nacional (1967/1972)", Nuevo Mundo Mundos Nuevos, París, 2018, 1-20. 
“Montoneros y la resistencia: identidad política y estrategia de lucha (1970-1980)", Quinto Sol, Vol. 23, No 1, enero/abril, La Pampa, 2019, 1-20.

"Las memorias de la Resistencia Peronista en los orígenes de Montoneros", Travesía. Revista de historia económica y social, No 1, vol. 21, 1-27.

Montoneros y la memoria del peronismo, Prometeo, Buenos Aires, 2019.

-Pacheco, Julieta, "Análisis de la militancia sindical de Montoneros: la juventud trabajadora peronista y sus luchas", e-@latina. Revista electrónica de estudios latinoamericanos, No 50, 2014. -Pacheco, Mariano, Montoneros silvestres (1976-1983), Buenos Aires, Planeta, 2014.

-Perdía, Roberto, La otra historia. Testimonio de un jefe montonero, Río Negro, Grupo Ágora, 1997.

Montoneros. El peronismo combatiente en primera persona, Buenos Aires, Planeta, 2013

-Robledo, Pablo, Montoneros y Palestina. De la revolución a la dictadura, Buenos Aires, Planeta, 2018.

-Salas, Ernesto, De resistencia y lucha armada, Buenos Aires, Punto de Encuentro, 2013

-Salcedo, Javier, Los montoneros del barrio, Tres de Febrero, Universidad Nacional de Tres de Febrero, 2011.

-Servetto, Alicia, 73/76, el gobierno peronista contra las "provincias montoneras", Buenos Aires, Siglo XXI Editores, 2010.

-Slipak, Daniela, "Revolución y justicia: disciplina, delitos y juicios en la revista Evita Montonera", Lucha armada en la Argentina, Ejercitar la memoria editores, 2013

"Sobre desvíos, espejos y cúpulas. Las disidencias montoneras y las lecturas sobre

los años setenta", Izquierdas, No 32, Santiago de Chile, 2017, 1-13.

"Comunicar la disidencia. Un recorrido por tres escisiones de Montoneros en los setentas", Izquierdas, No 14, Santiago de Chile, 2018, 141-161.

-Vinelli, Natalia, Radio Liberación TV. Comunicación, agitación y propaganda para la Contraofensiva montonera en años de dictadura militar, tesis de grado, FSOC/UBA, 2017.

-Vignollés, Alejandra, Doble condena. La verdadera historia de Roberto Quieto. Secuestrado por los militares y acusado de traición por los montoneros, Buenos Aires, Sudamericana, 2011.

-Zúcker, Cristina, El tren de la victoria. La saga de los Zúker, Buenos Aires, Del Nuevo Extremo, 2010.

Documentos

-Baschetti, Roberto, Documentos 1973-1976. De la ruptura al golpe, La Plata, de la Campana, 1999.

Documentos 1976-1977. Golpe militar y resistencia popular, Volumen I, La Plata, De la Campana, 2001

-“Bases para la Unidad Nacional. Declaración Constitutiva de la CGTR” (agosto 1976), www.eltopoblindado.com

-Boletín de la Rama Femenina del MPM, (1979, s/d), www.eltopoblindado.com

-El Descamisado edición Centroamérica, www.eltopoblindado.com

-El Montonero, www.eltopoblindado.com

-Estrella Federal, www.eltopoblindado.com

-Evita Montonera, www.eltopoblindado.com

-Los papeles de Walsh, (noviembre 1976-febrero 1977), www.eltopoblindado.com 
-“Movimiento Peronista Montonero. Convocatoria al pueblo argentino”, www.eltopoblindado.com

"Presentación en Roma del Movimiento Peronista Montonero", El País, 22/4/1977.

-Vencer, www.eltopoblindado.com

- "Una carta polémica”, www.eltopoblindado.com

-“Montoneros 17 de octubre: una naciente fuerza política”, www.eltopoblindado.com 